\title{
Town engineers in South Africa before 1910, with reference to water supply
}

\author{
$H M \ddot{A} K I^{*}$
}

\begin{abstract}
This article looks at the town engineers in South Africa prior to Union in 1910. It briefly examines the growth in the number of municipalities and town engineers in the country in this period and investigates the background and training of these engineers; why municipalities decided to appoint an engineer; and what kind of appointment processes were followed. Finally the relations between engineers and town councils and the prevailing circumstances at the end of the engineers' tenures is studied. The article also presents ten specific cases which have reference to the development of water supply. It emerges that most early town engineers received training via apprenticeship for the positions they held, and that there was added pressure from elected councillors in municipalities who were prone to monitor assiduously how officials were spending public money. It is also clear that engineers who did not have earlier municipal experience were bound to have problems in their interaction with town councillors.
\end{abstract}

Keywords: Municipal history; civil engineering; water supply; sanitation; Cape Colony; Natal; Orange Free State; Transvaal.

Disciplines: History; Engineering; Public Management.

\section{Introduction}

When one studies municipal history in South Africa one has to look very carefully, often in vain, to find any mention of town engineers. The names of mayors and medical officers of health feature much more prominently. The history of public works has also become an important part of histories written on the development of South African local government and service delivery, but the identities and contributions of the engineers responsible for those works have for the most part been left out. Municipal engineers were appointed in South

Dr Harri Mäki is a Finnish water historian, assosiated wioth the University of Tampere. He is a senior research associate at the Research Niche for the Cultural Dynamics of Water (CuDyWat) North-West University (Vaal). E-mail: harri66maki@gmail.com

TD The Journal for Transdisciplinary Research in Southern Africa, 9(1) July 2013, pp. 139 - 158. 
African towns before the time period covered by this article. ${ }^{1}$ This research, however, begins from the 1850s, after the creation of the first municipalities in the Cape Colony a decade earlier. The end point of the research is the creation of the Union of South Africa in 1910.

In this article, there is a conscious effort to concentrate only on the top official of municipal public works departments, namely the municipal/town/borough/city engineer; all four versions were in use. This official was responsible for all public works under municipal governance. Other engineers working for the municipalities have been excluded from this study; in some towns, for example, there were separate electrical engineers, water engineers and sewerage engineers, who in most cases were working under the town engineer. In some cases municipalities had the same person acting as town clerk and town engineer, or even as town treasurer; these cases were taken into account when information was found on their identity. In some instances, exceptions to these guidelines were made.

All in all, every known town engineer in the Cape Colony, Natal, the Orange Free State and the Transvaal falls within the ambit of this research project. There were 120 engineers in 43 municipalities in this time period. In some cases, however, only a name is known, as was the case with J. Daniel, town engineer of Adelaide in 1909. In another instance the name of the first town engineer of Pietersburg (now Polokwane) is not divulged in the documents, although his resignation is recorded. Information on these engineers has been gleaned from various sources including town council minutes, mayors' minutes and records on membership of various engineering associations and institutes.

It has to be stressed that this is not a study of what these engineers achieved while employed as town engineers in their respective municipalities. This article presents an overview of the engineers themselves, where they came from, their backgrounds, how they were selected and why they left the employment of the particular local municipality. All-inclusive research of what these engineers actually did during their tenures is beyond the scope of this article.

There is, nevertheless, a section on water supply in the article. Here, a discussion is provided on certain engineers closely connected to the development of water supply in their respective municipalities. Water supply has been selected as a specific topic because the introduction and augmentation of water resources was one of the most important municipal issues in South Africa during the period under discussion. Considering the dry climate of South Africa, the provision of water, particularly to people in rural municipalities, still remains one of the most crucial issues.

\section{The establishment of municipalities and their employment of engineers}

\subsection{Cape Colony}

The first municipalities in the Cape Colony were established in the 1830s. ${ }^{2}$ At the beginning of the 1850s there were already 23 municipalities in the area. During the same decade the

For instance, Hendrik Oldenland, the superintendent of the Company's garden and land surveyor for the government, was apparently promoted to the position of first town engineer of Cape Town as early as 1693. See G.M. Theal, History of South Africa [1691-1795] (London: Swan Sonnenschein \& Co., 1888), p. 7. 
first town engineers were appointed in Cape Town, Port Elizabeth and Grahamstown. ${ }^{3}$ During the 1860s, the number of municipalities increased to 31 . The number of engineers, however, decreased. The first town engineer was appointed in three new municipalities during this decade but by 1869 , the only engineers were employed in Cape Town and Beaufort West. ${ }^{4}$ By the end of the next decade, there were 38 municipalities but the number of town engineers remained low. The town engineer of Beaufort West was dismissed in 1877 and for nearly two years James Tennant in Cape Town was the only town engineer in the southern African region.

In the 1880s, the number of municipalities in the Cape Colony increased considerably, with 27 new municipalities being established. But this increase still did not reflect a corresponding number of town engineers. There were five town engineers in the Cape Colony at the beginning of the decade and only two by 1889 . Cape Town was the only municipality which employed a town engineer for the entire decade. In the 1890s the number of municipalities continued to grow and by the end of the century there were 88 municipalities. During this decade, the appointment of town engineers also increased and there were nine town engineers employed in the Cape Colony in 1899. The number of municipalities grew to 115 during the first decade of the twentieth century and there was a marginal increase in those that employed an engineer; this tally rose from 11 in 1900 to 19 in 1909, but then decreased again to 17 in 1910.

\subsection{Natal}

In Natal, the first municipalities, Durban and Pietermaritzburg, were established in the 1850s. The first borough engineer was appointed in Pietermaritzburg for a few years during this decade. ${ }^{5}$ In the 1860s and 1870s Natal experienced slow growth at the local government level and there were no new municipalities created. However, in Pietermaritzburg they again employed an engineer for a few years in the 1860s. There was only one new municipality established in the 1880s, namely Ladysmith. Pietermaritzburg and Durban both appointed borough engineers in $1882 .{ }^{6}$ In Pietermaritzburg it was again only for less than two years that

2 L.P. Green, History of Local Government in South Africa: An Introduction (Cape Town: Juta, 1957), pp. 16-21.

3 Western Cape Provincial Archives (hereafter WCPA), Town Clerk, Cape Town (3/CT) 1/1/1/15, Board of Commissioners, 26 April 1854; WCPA, Town Clerk, Port Elizabeth (3/PEZ) 1/1/1/2, Board of Commissioners, 18 and 25 November 1857; WCPA, Town Clerk, Grahamstown (3/AY) 1/1/1/5, Board of Commissioners, 28 January 1859.

J.A. Bateman, The Borough of King Williams Town: A Century of Public Service (King Williams Town: Progress Printing, 1961), pp. 9-13; C.G. Henning, Graaff-Reinet: A Cultural History, 1786-1886 (Cape Town: T.V. Bulpin, 1975), pp. 73-74; W.G.H. and S. Vivier, Hooyvlakte: Die Verhaal van Beaufort-Wes, 1818-1968 (Cape Town: Nasionale Boekhandel, 1969), pp. 25-26.

5 E.N. Meineke and G.M. Summers, Municipal Engineering in Pietermaritzburg: The First Hundred Years (Pietermaritzburg: City Engineers Department, 1983), pp.14-15.

6 Kwazulu-Natal Provincial Archives (hereafter KNPA), Durban Archives Repository (hereafter TBD), Town Clerk, Durban (3/DBN) 1/1/1/16, Town Council, 17 January 1882; KNPA, Pietermaritzburg Archives Depository (hereafter NAB), Town Clerk, Pietermaritzburg (3/PMB) 1/1/5, Town Council, 27 November 1882.

$$
\text { TD, 9(1), July 2013, pp. } 139 \text { - } 158 .
$$


the engineer remained in office, while in Durban, they have had an engineer continuously thereafter. By the end of the century, the fourth municipality, Newcastle, was established. In 1893 Pietermaritzburg again appointed an engineer but this time in a permanent capacity. Two new municipalities were established before 1910 - Dundee and Weenen. Besides Durban and Pietermaritzburg, there were borough engineers in Newcastle and Ladysmith for short periods during the 1900s.

\subsection{Free State}

In the Free State, the first two municipalities were established in the 1850s and thereafter the number of municipalities grew gradually. In the 1860s, there were two new municipalities; in the 1870s eight; and in the 1880s two. During the last two decades under examination, there were respectively twelve and ten new municipalities. The first town engineer, however, was appointed only in 1898 in Bloemfontein. ${ }^{7}$ During the 1900s, engineers were also employed in Kroonstad, Harrismith and Parys. ${ }^{8}$

\subsection{Transvaal}

In the Transvaal, the development of local government differed considerably from other areas. During the 1860s, there were municipal experiments in Potchefstroom and Pretoria and in the 1870s, municipal regulations were published for four new municipalities. ${ }^{9}$ All these municipal experiments ended in the 1880s. ${ }^{10}$ Nevertheless, the first town engineer was appointed in Johannesburg in $1889 .{ }^{11}$ However, it should be remembered that Johannesburg was not a municipality at the time but a mining area controlled by a sanitary board. ${ }^{12}$ During the last decade of the nineteenth century, Johannesburg and Pretoria were granted municipal self-government and in Pretoria the first town engineer was appointed. Permanent municipal government, however, was only introduced under British control after the Anglo-Boer War of 1899-1902.13 Ten new municipalities were formally established in 1903/1904. Furthermore, a number of urban district boards were created in 1903. They were granted municipal status later in 1904, but were called minor municipalities, whereas the ten municipalities mentioned above, plus Johannesburg and Pretoria, were called major municipalities. Roodepoort-Maraisburg became a major municipality in 1905 and Benoni

Free State Provincial Archives (hereafter VAB), Town Clerk, Bloemfontein (MBL) 1/1/1/9, Town Council meeting, 21 July 1898.

There might well have been an engineer in Ladybrand too but since Provincial Archives in Bloemfontein do not hold the relevant material and there was no possibility for the researcher to visit Ladybrand, this information could not be verified.

Green, History of Local Government, pp. 52-54.

Green, History of Local Government, pp. 56-60.

'The New Town Engineer', The Star, 27 November 1889. The appointment was seen as so important that The Star commented in its editorial, See 'The Man who Makes a Town', The Star, 12 December 1889.

H. Mäki, Water, Sanitation and Health: the Development of the Environmental Services in Four South African Cities, 1840-1920 (Tampere, KehräMedia, 2008), pp. 42-48. 
was separated from Boksburg and was proclaimed a major municipality in 1907. Of the major municipalities, eight had town engineers in 1910; among the minor municipalities the only one to appoint a town engineer was Volksrust.

\subsection{General development}

In Figure 1 below, the growing number of town engineers in South Africa is shown. The numbers are presented for every fifth year and by state. What can be seen is that the number of municipalities which had appointed an engineer only began to increase at the end of the 1890s. One reason for this is that most of the small municipalities in the Cape Peninsula appointed town engineers at about this time. The other reason is that after the Anglo-Boer War smaller municipalities in the Orange River Colony and especially those in the Transvaal, began to appoint town engineers.

The effect of the economic depressions in the 1860s, 1880s and 1900s is also indicated in Figure 1. In the 1860s and 1880s, the number of the engineers in the Cape Colony decreased. The effect of the depression of the 1900s was different in that the number of engineers in the Cape Colony still increased but in the Transvaal it decreased.

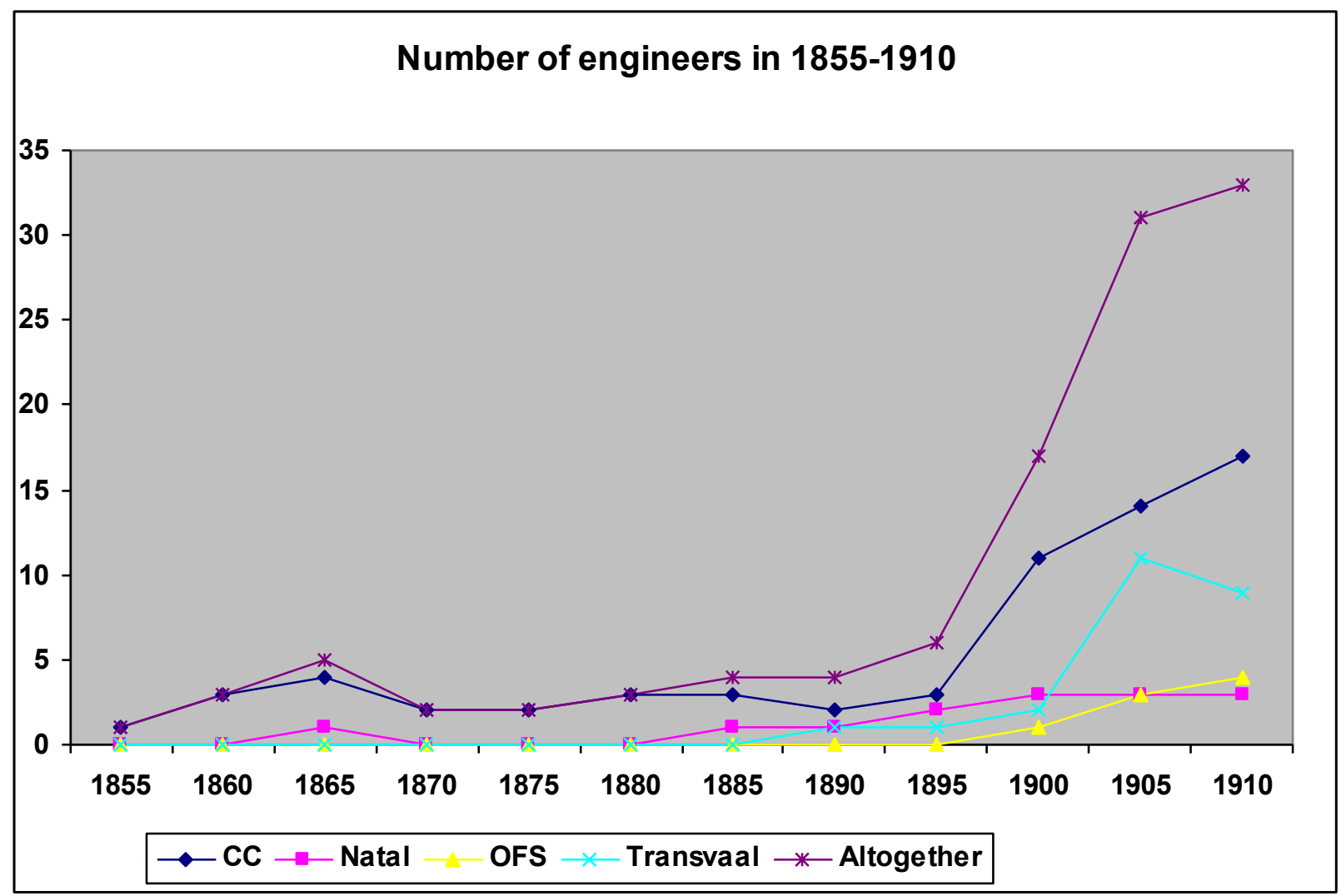

Figure 1. The number of town engineers, 1855-1910.

When considering the development in the number of municipalities and the appointment of town engineers, the Orange Free State immediately draws the attention. There were 26 municipalities in the Free State before the first town engineer was appointed in Bloemfontein. The main reason for this was that municipalities were small and poor. Some of them, like Bloemfontein, had a water bailiff taking care of the water supply. It seems that 
during the nineteenth century municipalities either did not see any necessity to appoint a town engineer or could not afford it. Considering the economic development in the decade after the Anglo-Boer War, the latter explanation seems more plausible.

Of the overall trends, it can be said that even if the first engineers were appointed in the 1850s, the number of municipalities having an engineer only began to increase at the end of the 1890s. Around this time, the small municipalities in the vicinity of Cape Town had grown so populous that they started to appoint engineers. The other jump in numbers was after the Anglo-Boer War when the municipalities in the northern colonies with an engineer went from three to fifteen. The same development can be seen when looking at the proportion of municipalities that employed an engineer. From 10 percent in 1860 it went down to 4.8 percent in 1890. It then turned upwards to 14.2 percent in 1900 and 18 percent in 1910. The number of municipalities increased from 18 in 1850 to 181 by 1910 .

\section{Background and training of the engineers ${ }^{14}$}

Most of the engineers, whose origin is known, were from Europe. All six engineers who are known to have come from outside Europe and South Africa were from Australia and Canada. Only five of the engineers were born in the current South Africa, all of them in either the Cape Colony or Natal. Of the 77 engineers coming from Europe, only four did not come from Britain; they came from Sweden, Germany, Netherlands and Hungary. The number of engineers from Britain is hardly surprising since the Cape Colony and Natal were part of the British Empire during the entire period under discussion. In the Orange Free State and the Zuid-Afrikaansche Republiek (ZAR) there were only seven engineers in total in three municipalities before the Anglo-Boer War. Two of the four engineers who were not from the British Empire were among these seven. Based on the names of the engineers whose background is unknown it appears that they were (with one possible exception) from the English-speaking part of the world.

The educational background of only 70 of the engineers is known. They had all undergone at least an apprenticeship level of training. Considering that most of the other 50 engineers were qualified engineers, it is safe to assume that most of them had gone through the same training system. Of the 70 engineers, a quarter of them had either a university degree or had studied at university, while ten had been apprenticed after this tertiary education. It was also not uncommon that a young man was apprenticed to his father.

It is not surprising that most of the engineers were civil engineers but there was a strong contingent of mechanical, especially railway engineers among them too. Especially in earlier years, there were also surveyors and architects who were employed as town engineers. Half of the engineers whose earlier career is known were already working in another lower position in municipal organisations. Nevertheless, there were also many who came from private companies or from government service.

This section is based for the most part on information collected from the archives of the Institute of Civil Engineers and the Institute of Mechanical Engineers in London. The Candidate Circulars and the Proposals for Membership in the archives include the descriptions of the engineers' earlier careers. 


\section{Why municipalities decided to appoint engineers}

In most cases the main reason for appointing the first town engineer in a municipal post was the need for proper supervision of public works. This was why 24 out of 42 engineers were appointed in this period, although there might have been other subsidiary needs too. Moreover, it can be speculated that most of the ten municipalities where the reason is unknown also belong to this category.

In two municipalities, Durban in 1882 and Umtata in 1909, the appointment was specifically made because of the need to establish and maintain an adequate water supply to residents. ${ }^{15}$ In many other municipalities, the needs of water supply were also high in the list, but only in the two mentioned cases was the appointment based primarily on the need for a reliable supply of water. The only other municipality where the appointment was based on a very specific need was Pietermaritzburg. There, in 1851, a proper town survey was needed and a surveyor was appointed. As an afterthought he was also appointed as an engineer for the borough. ${ }^{16}$

In four cases, the first town engineer was an earlier official whose designation was changed. In Kimberley, Thomas Callen was clerk of works; in Newcastle, George Jenkins was previously foreman of works; in Claremont, James Maden had been a municipal inspector; and in Uitenhage, Walter J. Mason served in the capacity of the superintendent of works. Their designations were changed to that of engineer in 1887, 1900, 1901 and 1907 respectively. ${ }^{17}$

The appointment in Bloemfontein was one of the most noteworthy. It appears that the municipality was not even planning to appoint a borough engineer in 1898, but was forced to do so. Bloemfontein needed a resident engineer for their waterworks and H.F. Peet was duly appointed. However, he refused to accept the job unless a tenure of more than one year was offered. The town council responded by offering him the position of borough engineer for two years. After further negotiation, a hard-bargaining Peet finally accepted when the tenure of the post was fixed at four years. ${ }^{18}$

In six municipalities, namely Pietermaritzburg, Grahamstown, Port Elizabeth, GraaffReinet, East London and Newcastle, there were periods when there was no town engineer. ${ }^{19}$ In Pietermaritzburg, there were three gaps; in Grahamstown, Port Elizabeth and Graaff-

TBD, 3/DBN 1/1/1/1/15, Town Council meeting, 27 September 1881; Durban, Mayor's Minute, 1882, p. 7; WCPA, Town Clerk, Umtata (3/UTA) 1/1/1/17, Municipal Council special meeting, 14 September 1909.

Meineke and Summers, Municipal Engineering, pp.14-15.

WCPA, Town Clerk, Kimberley (3/KIM) 1/1/1/1, Town Council meeting, 23 February 1887; B.C. Baylis, A History of Nerwcastle, vol. 3 (Newcastle: The Newcastle Advertiser, 1951), p. 5; South African Who's Who (Durban and Johannesburg: South African Who's Who Publishing Company, 1908), p. 259; WCPA, Town Clerk, Uitenhage (3/UIT) 1/1/1/29, Town Council meeting, 26 November 1907.

There are also gaps in the information on King Williams Town and Queenstown, but since it is not known whether there were engineers during these gaps, they are not included in this analysis. 
Reinet there were two gaps; and in East London and Newcastle one gap each during the period under consideration. When looking at the reasons for appointing a new engineer, in some cases after a considerable period of vacancy, it can be seen that they were for the most part the same reasons as for the appointment of the first town engineer.

In four cases, Pietermaritzburg in 1864 and 1882; Grahamstown in 1879; and East London in 1897; of eleven in this category, the reason behind the appointment was the need for public works. ${ }^{20}$ In the other four cases, Port Elizabeth in 1881 and 1897; and Graaff-Reinet in 1881 and 1901; the need for re-appointment was based on the necessity of establishing an adequate water supply. ${ }^{21}$ In two cases, Pietermaritzburg in 1893; and Grahamstown in 1907; the reason for appointing an engineer was a changed designation because of the need for public works. ${ }^{22}$ In Newcastle in 1909, the reason behind the appointment after a hiatus of five years is unknown.

\section{Application and appointment process}

\subsection{Applying for the position of town engineer}

There were at least 80 cases where applications were invited for the position of town engineer; the actual number of people who applied is known in 50 cases. The position of town engineer was much sought-after, drawing an average of 40 applications when advertised. The highest number of applicants was 130 when a post in Grahamstown was made known in 1907. At the other end of the scale was Cape Town in 1857, with only three applicants. ${ }^{23}$ There was a fair amount of variation in the number of applications, with six cases drawing more than 100 applications and 11 cases having a response of less than 15 applications. ${ }^{24}$

NAB, 3/PMB 1/1/3, Town Council meeting, 9 March 1864; NAB, 3/PMB 1/1/5, Town Council meeting, 27 November 1882; M. Gibbens, 'Two Decades in the Life of a City: Grahamstown 1862-1882', M.A. dissertation, Rhodes University, 1982, pp. 154-155; WCPA, Town Clerk, East London (3/ELN) 1/1/1/10, Municipal Council meeting, 12 May 1897.

WCPA, 3/PEZ 1/1/1/31, Town Council meeting, 2 February 1881; WCPA, 3/PEZ 1/1/1/17, Town Council meeting, 14 July 1897; WCPA, Town Clerk, Graaff-Reinet (3/GR) 1/1/1/6, Town Council meeting, 25 March 1881; WCPA, Public Works Department (PWD) 2/10/27, M19/32, McMillan to the Secretary of Public Works, 4 May 1903.

22 Meineke and Summers, Municipal Engineering, pp. 20-21; WCPA, Town Clerk, Grahamstown (3/AY) 1/1/1/15, Town Council meeting, 21 August 1907.

Grahamstown Mayor's Minute, 1908, pp. 4-5; WCPA, 3/CT 1/1/1/17, Board of Commissioners meeting, 18 November 1857. 


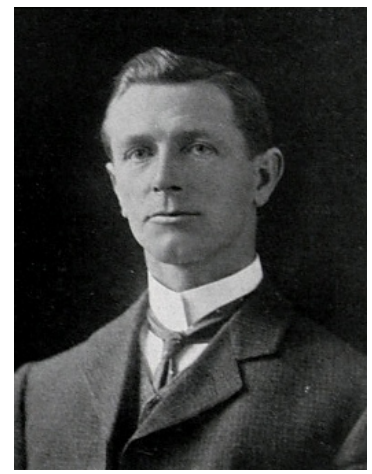

Figure 2. G.S. Burt Andrews ${ }^{25}$

It can be seen both from the number of applications and the engineers who applied, that a position in certain large municipalities, such as in Johannesburg, drew significantly more interest (no doubt because of better pay) than one in a smaller municipality. For instance in 1893, amongst the applicants for a post in Johannesburg were three former town engineers. Five of the applicants for this position in 1893 subsequently served as town engineers in some South African municipality. ${ }^{26}$

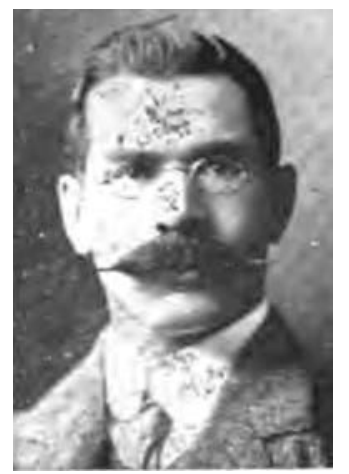

Figure 3. A.H. Waller ${ }^{27}$

In some cases, engineers found it necessary to apply multiple times before being appointed in a certain position. Peter Penketh was appointed town engineer of Cape Town at his third attempt, while G.S. Burt Andrews (Figure 2), town engineer of Johannesburg, eventually succeeded at his fourth try. There were also some engineers who applied very actively in certain time periods for advertised positions. From 1898 to 1901, A.H. Waller (Figure 3) applied for a post in Cape Town, Wynberg and twice for a post in Woodstock until he was finally appointed assistant borough engineer of Durban. Another active applicant was James Younger, who in the period from 1905 to 1907 applied for positions in Pietersburg, Potchefstroom, Germiston and East London. ${ }^{28}$

In many cases the numbers may have been inflated by applicants with doubtful qualifications. The definition of an engineer, especially during the earlier part of the examination period,

25. Men of the Times: Pioneers of the Transvaal and Glimpses of South Africa. Transvaal Publishing Company, 1905

26 The Star, 25 March 1893.

27 The Natal Who's Who. (An Illustrated Biographical Sketch Book of Natalians). Durban: Natal Who's Who Publishing Company, 1906.

Mäki, Municipal Engineers, pp. 76-78.

TD, 9(1), July 2013, pp. $139-158$. 
was very fluid, and many of the applicants were certainly not members of any engineering institutes. Nevertheless, the competition was fierce with good candidates to choose from.

\subsection{Appointment process}

In most cases, when a municipality needed a new town engineer, the position was advertised in the local newspapers and those of the bigger cities in South Africa. In some cases, particularly for positions in major cities, the post was also advertised in British newspapers. In a single instance, in Johannesburg in 1902, the position of town engineer was advertised only in British newspapers.

There were, however, some appointments that were not advertised. In three cases, appointments were made either on personal recommendation or directly by the municipal council. In Grahamstown in 1859, Robert Hoggar was recommended for the position of town engineer by a local justice of the peace. ${ }^{29}$ And in other cases, the position was offered directly to a person already working for the municipality as happened in Port Elizabeth in 1857, when the position was offered to Canadian-born Robert Archibald. ${ }^{30}$ In four known cases, the assistant engineer was promoted. There were also instances where the designation of the person was changed to that of town engineer.

The applications were usually sent to either a special committee appointed for the purpose or to an existing committee, to make a recommendation to the town council. In some cases, however, all the town councillors went through the applications. In many of these cases, the reason was a low number of applications. The exception was in Woodstock in 1898 where there were 98 applications that were scrutinised by the entire town council before a shortlist of six was selected for further consideration. ${ }^{31}$ In 19 of the cases when the matter was placed before the town council, it took a unanimous decision on who to appoint. In 36 cases, there were from one to four rounds of voting involved. In some instances, interviews were conducted with the leading candidates as part of the selection process.

\section{Engineers and the town councils}

\subsection{Relations between the engineer and the town council}

When looking at the relationship between the town engineer, the town council and the various committees the engineer had to work with, it is difficult to make any generalisations about good working relations. There are no apparent patterns here. Nevertheless there are two municipalities, Durban and Bloemfontein, which merit special mention. During the period under discussion, Durban employed two borough engineers, John F.E. Barnes (Figure 4) from 1882 to 1887, and John Fletcher (Figure 5) in the period 1889-1918.

29 WCPA, 3/AY 1/1/1/5, Board of Commissioners meeting, 28 January 1859.

30 WCPA, 3/PEZ 1/1/1/2, Board of Commissioners meeting, 16 December 1857.

31 WCPA, Town Clerk, Woodstock (3/WSK) 7, Town Council meeting, 19 December 1898. 


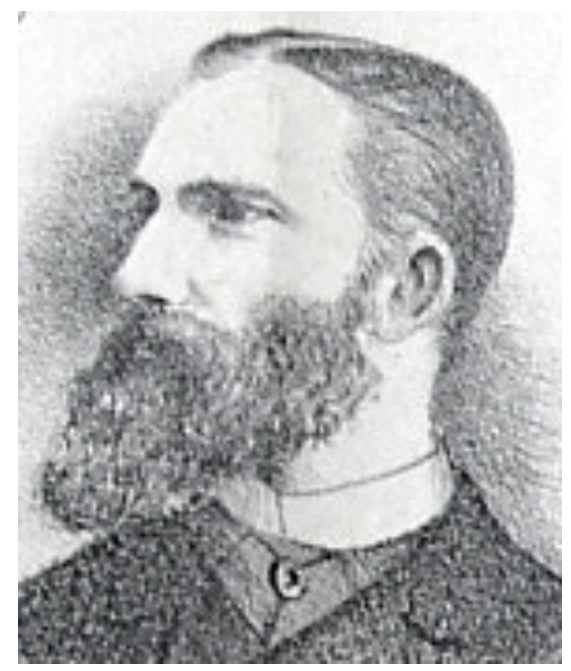

Figure 4. John F.E. Barnes ${ }^{32}$

It seems that neither had any problems getting their proposals approved for building new infrastructure. It is especially remarkable how few problems there were during Fletcher's 29year tenure. ${ }^{33}$ In Bloemfontein there were three city engineers: H.F. Peet (1898-1908); H.A.C. Wallace (1908); and G.A. Stewart (1908-1920). Although Peet resigned because he would not accept a lower salary, his departure was amicable. Wallace resigned because of health reasons but continued as the assistant city engineer for 15 more years, and Stewart resigned to apply for a government position.

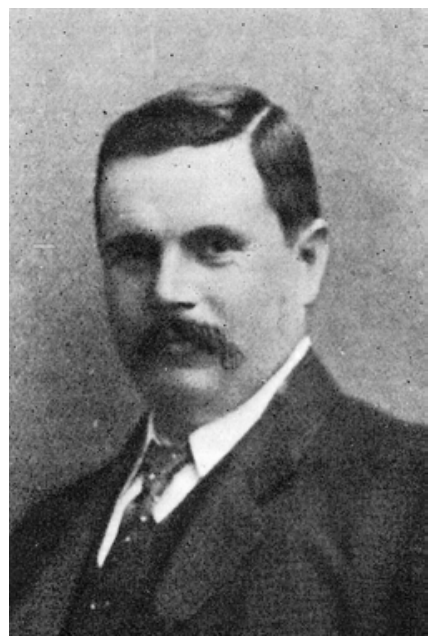

Figure 5. John Fletcher $^{1}$

32 Natal Mercury Christmas Annual 1886.

33 H. Mäki, 'John Fletcher and the Development of Water Supply and Sanitation in Durban, 1889-1918', Journal of Natal and Zulu History, 27 (2009), pp. 43-59.

TD, 9(1), July 2013, pp. 139 - 158. 
However, there are instances when engineers experienced problems in their working relations, and some generalisations can be offered. If, for example the engineer came from a totally different working culture and environment without any earlier experience of the municipal decision making process, there were bound to be difficulties. The prime examples are the engineers with a background in railways. They were used to a greater level of independence in decision making than they enjoyed in the municipal hierarchy. For instance, J.S. Swallow in Cape Town and John Gillespie in Pietersburg (now Polokwane) had most of their earlier working experience as railway engineers either in private companies or in the Cape Colonial Railways. Neither of these engineers could cope with the laborious municipal decision making process and this lead to Swallow's resignation after a year and Gillespie's after only five months in office. ${ }^{34}$

In some cases, the engineers were too innovative and progressive for conservative and moneyconscious councillors. The prime examples are W.L. Mackie in Graaff-Reinet, and W.F. Malloch in Uitenhage. Mackie was an English-speaking bachelor in a very conservative town where most of the residents could not even speak English. The final straw was a dispute with the chairman of the municipal board about salary reductions, and Mackie was dismissed in June $1865 .{ }^{35}$ W.F. Malloch, on the other hand, was apparently too innovative for the town council of Uitenhage and had lofty, over-ambitious plans. Slowly opposition against him and his schemes mounted until the council dismissed him when he went ahead with some work on the water supply to the town without prior permission from the council. ${ }^{36}$ And of course when there were difficult economic times, this was usually reflected in the relations between the town engineer and the decision makers.

Three specific municipalities, those of Cape Town, Pietermaritzburg and Graaff-Reinet, should be mentioned here. Of the 11 engineers in Cape Town, only Peter Penketh and William Jeffries seem to have been trouble-free in their relations with the councillors. All the others experienced some kind of friction. In Pietermaritzburg, the first six engineers either resigned or were dismissed. Graaff-Reinet had only three engineers during the period under discussion but all left the town after disagreements with the town council. In this case, the problems were probably compounded by the cultural clash between the British engineer and the remote Afrikaner-dominated country town.

WCPA, 3/CT 1/1/1/32, Town Council meeting, 8 March 1882; E.B. van Heyningen, 'Public Health and Society in Cape Town, 1880-1910', PhD. thesis, University of Cape Town, 1989, pp 259-260; National Archives of South Africa (hereafter NASA), Public records of the former Transvaal Province (hereafter TAB), Town Clerk, Pietersburg (MPB), 1/2/4, Minutes of the General Purposes Committee, 17 March 1908.

Henning, Graaff-Reinet, pp. 73-74; A. de V. Minnaar, Graaff-Reinet 1786-1986 (Pretoria: Human Sciences Research Council, 1987), pp. 14-15.

A. Herholdt, 'The Colonial Municipality: A Case Study of Uitenhage', South African Journal of Cultural History, 5, 3 (1991), p. 82; A.D. Herholdt, 'Uitenhage: A Case Study of Small Town Colonial Architecture', M.Arch. dissertation, University of Port Elizabeth, 1988, p. 66; D. Raymer, Streams of Life: The Water Supply of Port Elizabeth and Uitenhage (S.1.: s.n., 2008), p. 160. 


\subsection{Reasons for leaving the position}

When examining the reasons why engineers left their posts, it can be seen that 30 of them left involuntarily, while 69 chose to leave. There is insufficient information on why the remaining 19 engineers vacated their positions. Of those who left voluntarily, 23 made the change to take up another position; 11 went into retirement; and four resigned because of illhealth. Differences with either the town council or one of the municipal boards led to the resignation of 11 engineers. ${ }^{37}$ In 13 cases there is no clear reason for resignation.

The most intriguing case is that of James J.A. Flower in Cape Town. He was appointed as town engineer in early 1872 but was immediately allowed leave of absence. He resigned in January 1873 without leaving England during his entire 11- month tenure. Flower was working in London as a representative for a family firm from Cape Town and apparently chose to remain in this position rather than returning to Cape Town. ${ }^{38}$

Of those who left their positions involuntarily, three died in office and three had their contracts terminated. In 7 cases the engineers were forced to resign and in 17 instances the engineers were dismissed outright.

The case of Charles Rees is unique. He was appointed as town engineer of Cape Town in August 1873. In November 1874, the town council discovered that he was also holding a position with the Royal Engineers. Rees was given the choice to resign from the one position or the other but claimed that he could not resign from the Royal Engineers, so the Cape Town municipal council removed him from the office of town engineer. However he remained in an acting capacity while the position was being advertised. ${ }^{39}$ To the astonishment of all concerned, Rees re-applied for his old job stating that his connection with the Royal Engineers' Department might well be terminated within 18 months, and that should his Cape Town application be successful he would do his utmost to termination his other commitment within nine months. The special joint committee appointed for the screening of the candidates, pointed out in September 1875 that besides being incompatible with the existing regulations for an officer of the municipality to hold a situation elsewhere, the duties of the town engineer were so important as to require the entire and undivided attention of the official concerned. They deemed that the condition in Rees's application was unacceptable. It was recommended that he be appointed as Cape Town's town engineer pending the immediate termination of his situation with the Royal Engineers. If he failed to comply with this stipulation then Charles Hanson, another applicant, would be appointed. It was, however, moved that the appointment would stand over for six months, and that Rees be requested to continue to act as town engineer. ${ }^{40}$ In January 1876, the town council finally

37 It can be questioned how voluntary these resignations were, but since these cases differ from those of forced resignations in that there are no signs of a "resign or get dismissed" situation, they have been put in the voluntary category.

Obituary, James John Alexander Flower, Minutes of Proceedings of the Institute of Civil Engineers, 95 (1889), pp. 384-385. 
dismissed Rees and called for new applications because there had been no change in Rees' situation. ${ }^{41}$ He was still working as a surveyor in the Royal Engineers' Department in $1879 .{ }^{42}$

In a broader context, one engineer out of four was either dismissed, forced to resign, had his contract terminated, or died in office. The dismissed engineers (17) are the second biggest group, after those (23 engineers) who resigned when they secured another position.

\section{Specific cases with regard to water supply}

In this section a discussion of ten engineers who were connected specifically to the development of water resources, will be provided in more detail. Some of these cases have been selected for presentation mainly to show the difficulties these town engineers faced in their interaction with the members of the town council and the municipal residents in general. As will be shown, in smaller and poorer municipalities, financial considerations were particularly challenging in the construction and provision of water supplies. Furthermore, as is evident in the case of James Tennant, stringency measures were sometimes of concern even in bigger municipalities.

Avon Bruce-Brand ${ }^{43}$ (Figure 6) was born in 1843 in Leslie, Scotland. In his younger days he worked as a bodyguard to Queen Victoria. He arrived in the Cape Colony at the beginning of the 1860s and joined the colonial railway department as an engineer. When the railway line reached Beaufort West, Bruce-Brand settled there and was town engineer for the period 1869-1877. Later he worked as a mine manager on the diamond mines in Kimberley. Prior to his appointment as town engineer, Bruce-Brand had been advocating for building a dam to the northeast of Beaufort West. The decision to build this dam was made in 1865, and construction was completed in early 1869. Bruce-Brand, who had led the construction work, was then appointed town engineer. The next autumn, however, flooding caused by heavy rains broke the dam and nearly 3000 million litres of water rushed through the town. After four and half years of debate, the town council eventually decided to rebuild the dam in 1874 . Bruce-Brand was again responsible for the construction work, but for unknown reasons he was informed in 1877 that his services were no longer required. The dam was completed three years later. ${ }^{44}$

WCPA, 3/CT 1/1/1/27, Town Council meeting, 26 January 1876.

42 Report of the Select Committee on the Oranjezicht Purchase Bill, 1879, p. 63.

43 For information on Bruce-Brand, the author is grateful to Pamela Bruce-Brand, whose husband is a direct descendant of Avon Bruce-Brand.

of

Beaufort

West,

http://gis.deat.gov.za/isrdp/staticsites/ss_k/Documents/Beaufort_West.pdf, p. 4; Vivier, Hooyvlakte, pp. 25-26. 


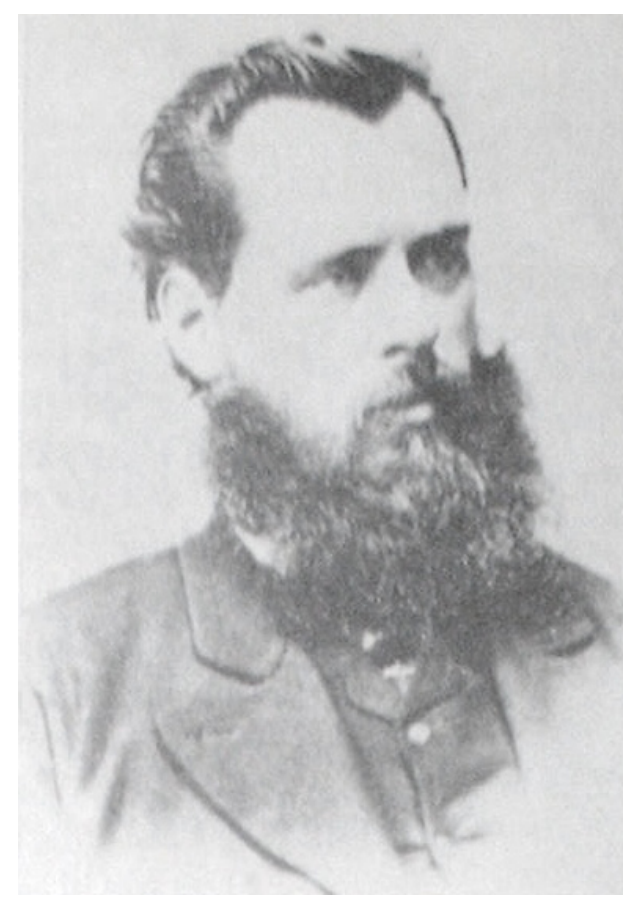

Figure 6. Avon Bruce-Brand ${ }^{45}$

James Tennant was born in 1839. He served in the British army engineering corps during the Sepoy mutiny in India in 1857-1859 and later in China. During the 1860s he was resident in the Cape Colony. Tennant went back to England to make a contribution in the construction of the Thames fortifications and then went to Ireland before returning to Cape Town in 1875. He was appointed as city engineer of Cape Town, a position he held from 1876 to 1880. In 1880 he was granted leave to take part in the Basotho War and during the war he resigned from his post as city engineer. Tennant later worked in Cape Town as a private engineer, surveyor and architect.

The construction of the Molteno reservoir was mainly due to Tennant's initiative. At this time, however, all big construction works in Cape Town were undertaken on tender by private contractors. Nevertheless the city fathers demanded that Tennant be solely responsible for supervising the construction of the reservoir in addition to his normal workload. They also altered the plans of the reservoir without consulting Tennant. All this led to a frustrated Tennant's request for leave of absence in 1880 and eventually to his resignation. The Molteno reservoir was completed in 1881 but its wall burst the following year when the reservoir was filled. The town councillors blamed Tennant for this catastrophe but John G. Gamble, hydraulic engineer for the colony, reported bluntly that the councillors had to shoulder sole responsibility for the mishap. ${ }^{46}$

45 Vivier, Hooyvlakte

46 WCPA, 3/CT 1/1/1/31, Town Council, 22 September and 3 November 1880; J. Lison, 'A Short, Tragic History of the Molteno Reservoir', Cabo, 2, 1 (1978), p. 26; Van Heyningen, 'Public Health and Society', p. 259; J.G. Gamble, Water-Supply in the Cape Colony (London: Institute of Civil Engineers, 1887), p. 28.

TD, 9(1), July 2013, pp. 139 - 158. 
W.L. Mackie was town clerk, treasurer and town engineer for Graaff-Reinet in 1863-1865. It is unknown what his credentials were as an engineer but he located the so-called Mackie's Pit that served as the main water source for Graaff-Reinet until the next century. Mackie quarrelled with the leading citizens of the town and was finally dismissed. According to Henning "the presence of a gay bachelor about town, who spent his money freely on liquor, playing cricket and paying attention to the eligible ladies, was viewed unsympathetically by the more conservative, impoverished backstreeters". ${ }^{47}$

Humphrey Henchman had worked on railroads in England, Germany, Hungary and the United States before arriving in the Cape Colony in 1876. He worked for the colonial railway department as an engineer until 1880 and from 1881 to 1884 was town engineer of GraaffReinet. Thereafter, he held a variety of posts in the Cape Colony, the Straits of Malacca, New South Wales and India. ${ }^{48}$ Henchman was appointed town engineer of Graaff-Reinet specifically to build a new water supply system. However, some of the residents did not approve of his plans. Accordingly, the first motion for his dismissal was tabled by the town council a mere six months after his appointment. The task at hand was by no means easy for Henchman; for instance, all his proposals for street improvement were rejected and he was ordered to stop reading water meters which was seen as "a waste of time". He soon became the target for insults and humiliation and everything he did was criticised. ${ }^{49}$ Somehow Henchman managed to concentrate on his work and in April 1884 the water supply system was completed. However, when Henchman was ready to start the turbines and pumps, a group of people attacked him and threw him into the turbine basin. Henchman won the resulting court case against the attackers but understandably disconcerted and discouraged, he resigned in October 1884..$^{50}$

John F.E. Barnes was born in Kilkenny, Ireland in 1851. After his education at Trinity College, Dublin, he was apprenticed for five years under his father. Before going to Natal in 1879, Barnes worked as an engineer and surveyor in Northern Ireland. In Natal he was a government surveyor for two years before being appointed as the first borough engineer of Durban in 1882. Barnes resigned in 1887 after securing an appointment in the colonial engineers' department. During the period 1893-1910, he was chief engineer of public works in Natal. ${ }^{51}$

In Durban, the main reason for the appointment of a borough engineer was the need for a proper water supply and sewerage system. Barnes was seen as a most qualified applicant to realise these targets. Under his supervision the first water supply system that covered the

47 Henning, Graaff-Reinet, pp. 73-74; Minnaar, Graaff-Reinet, pp. 14-15; A. de V. Minnaar, 'Graaff-Reinet's Water Problems', Contree, 7, 22 (1987), 24.

KNPA, NAB, Colonial Secretary's Office (CSO) 1286, 1891/1423, Henchman to Colonial Secretary, Natal, 17 January 1891.

WCPA, 3/GR 1/1/1/6, Town Council, 25 March and 24 October 1881; The Graaff-Reinet Herald, 30 April 1881.

The Graaff-Reinet Herald, 23 April 1884; Henning, Graaff-Reinet, 86-88.

51 Obituary, John Frederick Evelyn Barnes, Minutes of Proceedings of the South African Society of Civil Engineers, 23 (1925), 234. 
entire central area of Durban was built. Building of storm water drains and planning of sewers were also started but the realisation of these was left to his successors. ${ }^{52}$

John Fletcher was born in 1858 in North-East England. Before his appointment as borough engineer of Durban in 1889, he had worked as assistant engineer of Nottingham; engineer of the Auston Rural Authority; and town engineer of Sutton Coldfield. After almost 30 years of service in Durban, he retired in 1918 because of ill-health. ${ }^{53}$

The main reason for Fletcher's appointment was his experience on sewerage systems. Before tackling this problem in Durban, he had to plan extensions of the water supply system which his predecessor, John Barnes, had begun; Fletcher's new plants were opened in 1891. In the same year, he finalised plans for a sewerage system. These projects were seen as so important that reports were published in the Natal Mercury, covering two and a half pages out of four in the newspaper. By 1889 Fletcher had finalised his plans for new stormwater drainage. He remained in his post for 29 years as borough engineer of Durban, so it is inevitable that his handiwork can be seen in all public works during those years. Nevertheless, it has to be said that especially during the nineteenth century, most of his time was spent in various works dealing with water supply and sewerage issues. ${ }^{54}$

Thomas Stewart was born in Perthshire, Scotland in 1857. After serving an apprenticeship, he studied at the Glasgow University, Anderson College and College of Science and Arts for various subjects related to engineering. He also worked as assistant engineer in the Glasgow waterworks and then at the office of J.W. Barry in Westminster. In 1882, Stewart arrived in the Cape Colony to work as assistant to the colonial hydraulic engineer. During the years 1885-1886 he headed the department and from 1886 to 1887, he served as engineer for the Cradock waterworks. From 1889 onwards Stewart was consulting engineer for the municipality of Wynberg. In the 1890s, he quickly became the most actively employed private engineer for planning waterworks in the Cape Colony and neighbouring areas. Among other projects, Stewart planned all five reservoirs on Table Mountain; the storage reservoirs and filter beds for Port Elizabeth; and worked as consulting engineer for Johannesburg Waterworks Company. Outside current South Africa, he also planned engineering works in Rhodesia and Portuguese East-Africa. ${ }^{55}$

John Hamilton Wicksteed (Figure 7) was born in Leeds in 1851. He studied at University College School, London before doing his apprenticeship in Leeds. He then worked on various water supply and sewerage projects. In 1877, he was appointed as a water supply engineer for Van Staden's waterworks in Port Elizabeth. When the works were almost complete, Wicksteed was appointed town engineer in 1881. However, he resigned only four months later complaining of extreme stress. Soon afterwards, Wicksteed committed suicide. ${ }^{56}$

KNPA, TBD, 3/DBN 1/1/1/15, Town Council, 27 September 1881; Durban, Mayor's Minute, 1882, p. 2; Mäki, Water, Sanitation and Health, pp. 123-126, 247.

Institute of Civil Engineers (ICE), London, Candidate Circular, John Fletcher.

Durban, Mayor's Minute, 1890, p. 2; W.P.M. Henderson, Durban: Fifty Years of Municipal History (Durban: Robinson, 1904); Mäki, 'John Fletcher'.

T. Murray, 'Past Master 19: Thomas Stewart', Civil Engineering, 16, 10 (2008), pp. 36-39.

D. Raymer, 'Past Master 22: John Hamilton Wicksteed', Civil Engineering, 17, 5 (2009), pp. 56-57; A. Herholdt, 'Architects and Architecture', Modus, 2, 1 (1987), p. 3; J.H. Wicksteed, $T D$, 9(1), July 2013, pp. 139 - 158. 


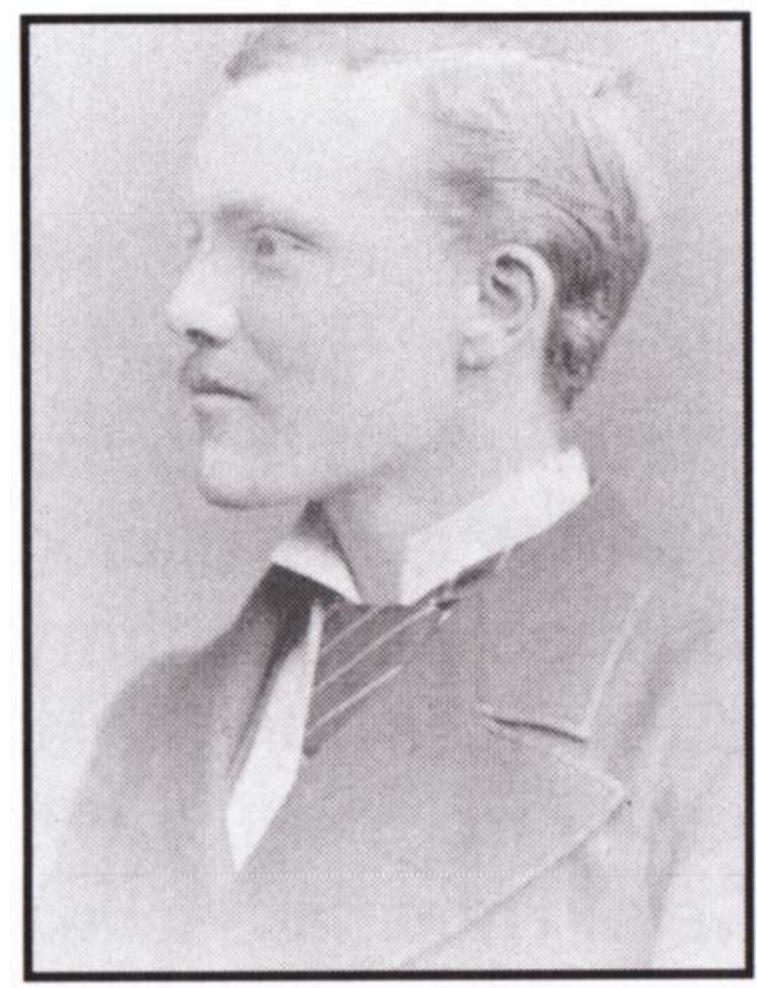

Figure 7. John Hamilton Wicksteed ${ }^{57}$

George Frederick Newsam had been working as town clerk of East London for six years when in 1881 the responsibilities of town engineer were added to his brief. The next year he resigned his position as town clerk and concentrated on developing plans for supplying water to the town from the Amalinda reservoir. This project was completed in 1884 during the economic depression and the following year the position of town engineer was abolished. ${ }^{58}$

William Dunbar was appointed town clerk and town engineer of King Williams Town in 1881. During the seven years in this position he concentrated specifically on improving the water supply. Under his supervision a new reservoir and a dam on the Buffalo River were built. However, both these initiatives were strongly criticised, especially because the final cost of the dam was three times higher than the original estimate. This criticism led to Dunbar's

Memorials of John Hamilton Wicksteed (London: Institute of Civil Engineers, 1883), pp. 232-233.

57 Raymer, 'John Hamilton Wicksteed'.

58 WCPA, 3/ELN 1/1/1/4, Municipal Council, 10 March 1881; WCPA, 3/ELN 1/1/1/6, Municipal Council, 29 April 1885; K. Tankard, 'The Effects of the "Great Depression" of the Late 19th Century on East London, 1873-1887', The South African Journal of Economic History, 6, 2 (1991), p. 81. 
resignation in 1888 and he went to Johannesburg to work as an engineer in the Johannesburg Waterworks Company. ${ }^{59}$

\section{Summary}

A picture of a typical town engineer in the period prior to 1910 can be drawn based on the text above. He was born in England and was trained through the apprenticeship system. There was also a strong probability that his father was also an engineer. His early working experience was mostly in the field of civil engineering and at the time of his appointment he was more than likely already working for another South African municipality in a subsidiary position. Our engineer was appointed after an application process and he probably had about 40 competitors for the position. Applications were scrutinised by a special municipal committee which then drew up a shortlist of three applicants for the town council. The new engineer was then appointed unanimously at the town council and most likely resigned after five years when he secured a better position elsewhere.

This picture is of course a simplification; there are many variations. Although most of the engineers were originally from England, there were a significant number who immigrated to South Africa from other parts of Britain. Engineers from outside of the English-speaking world were an exception and of the four known cases, three had come to South Africa to work in the independent Zuid-Afrikaansche Republiek in the eighteenth century, while the fourth, Wilhelm Westhofen, had been working in England for over 20 years before proceeding to South Africa. This means that the engineers predominantly represented the British tradition of engineering and this tradition was dominant in the period under consideration.

Although most of the engineers were already in South Africa when they were appointed, a significant number, especially those in the bigger cities, came directly from the mother country without any earlier experience of South African conditions or those in other parts of the British Empire. Surprisingly, it seems it that most of these engineers adapted reasonably well to the southern African working environment.

It is also important to realise that although most of the engineers had gone through the traditional apprenticeship system, there were also some who had university or technical school training. It is also noteworthy that many of the appointed engineers were not civil engineers but mechanical engineers, especially railway engineers. This being so, it is hardly surprising that engineers with prior experience in railway construction had more problems working within the boundaries of municipal regulations and dealing with local politics. During the early years there were also architects and surveyors among the ranks of town engineers. Towards the end of the nineteenth century the differences between various engineering professions began to be defined more clearly and after the $1880 \mathrm{~s}$, most of the town engineers came from the field of civil engineering.

It is clear that the need to supervise public works was the main reason why municipalities first appointed town engineers. In later appointments, specific needs became more prominent. The number of applications for the position varied significantly; in some cases the variation 
was so great as to be difficult to explain. Of course, lucrative positions like Johannesburg received many applications and were of a higher standard than those for smaller municipalities.

There was also a great deal of variation in the process followed in making the appointment. Advertising the position and calling for applications was the most typical, but there were others too. In some cases, an engineer was appointed directly; in others the designation of the position was changed. There were also cases where apparently the decision makers were dissatisfied with the standard of the applications. In such cases, the method usually followed was to call for new applications, while in others the entire process was postponed or the person appointed was not even among the applicants. The appointment was usually made after a special committee had gone through the applications and made its recommendations.

The position of engineer was insecure when difficulties arose in his interaction with municipal decision makers. It was only in the 1920s that laws regulating the dismissal of municipal officials were introduced. In the earlier years, three months' notice was the only job security town engineers enjoyed. There were bound to be problems if the engineer did not have any prior experience of the municipal decision making process. This can be seen in many cases. Engineers who had been working in the railway sector or in private business experienced considerable difficulty in adjusting to a working environment where there were strict boundaries and rules. In most instances, the town councillors were also very conservative in their thinking and a young, progressive engineer coming from a wider world was too much for them to accept. Consequently there were only 11 engineers known to have gone into retirement from their position. The large majority either resigned or were dismissed.

The difficulties faced by these early town engineers become even clearer when we consider the important issue of water supply. Augmenting the water supplies for residents of local municipalities was among the most expensive municipal initiatives undertaken in the period under examination. Town councillors typically monitored the engineer's progress very closely and were constantly alerted on how much was being spent. There were only a few instances where the cost of a project did not cause complaints and in many cases the engineer had to shoulder the blame. As was the case with Henchman in Graaff-Reinet, despite doing the best he could under the circumstances it was the engineer who had to go.

What was the influence of these engineers to South African engineering field? In this article the focus has been on town engineers and it can be said that the tradition of municipal engineering in the early twentieth century was predominantly British. This situation changed only later when the training of engineers was begun in South Africa and some of the engineers went overseas (for example to the Netherlands or Germany) to gain a higher degree in engineering. On the other hand, by studying the careers of individual engineers, it can be seen that many also had expertise in fields other than civil engineering. For example Arthur Henry Reid, who went into private business after his early years as a municipal engineer, became one of the most influential architects of his times in South Africa. 